\title{
Rhopalurus Junceus Venom Modulates the Expression of E6/E7 Viral Oncogenes of HPV-16 in SIHA Tumor Cell Line
}

\author{
Arianna Yglesias Rivera ${ }^{1 \# *,}$, Arlett Rubio Suárez ${ }^{2 \#, ~ M a r i t z a ~ P u p o ~ A n t u ́ n e z ², ~ Y u d i r a ~ S o t o ~ B r i t o ³, ~}$ \\ Celeste Ramírez Cardentey ${ }^{3}$, Jenny Laura Ruiz Fuentes ${ }^{4}$, Hermis Rodríguez Sánchez ${ }^{3}$ and Yandy \\ Ybalmea Gómez ${ }^{1}$
}

${ }^{1}$ Research Department, Laboratories of Biopharmaceuticals and Chemicals Productions (LABIOFAM), Havana, Cuba

${ }^{2}$ Biology Faculty, Havana University, Cuba

${ }^{3}$ Microbiology Virology Department, Sexually Transmitted Diseases Laboratory, Tropical Medicine Institute "Pedro Kourí", Havana, Cuba

${ }^{4}$ Laboratory of Molecular Cardiovascular Pathophysiology. Program of Physiology and Biophysics, Institute of Biomedical Sciences (ICBM), Faculty of Medicine, Universidad de Chile, Santiago, 8380453, Chile.

${ }^{\#}$ These two authors contributed equally to this work

*Corresponding author: Arianna Yglesias Rivera, Laboratories of Biopharmaceuticals and Chemicals Productions (LABIOFAM), Havana, Cuba

\section{ARTICLE INFO}

Received: May 19, 2021

Published: 㓞 June 02, 2021

Citation: Arianna Yglesias R, Arlett Rubio S, Maritza Pupo A, Yudira Soto B, Jenny Laura Ruiz F, et al., Rhopalurus Junceus Venom Modulates the Expression of E6/ E7 Viral Oncogenes of HPV-16 in SIHA Tumor Cell Line. Biomed J Sci \& Tech Res 36(2)-2021. BJSTR. MS.ID.005816.

Keywords: Rhopalurus Junceus Scorpion Venom; Viral Oncogenes E6 and E7; HPV16; Cervical Cancer; IL-1 $\beta$

Abbreviations: HPV: Human Papilloma Virus; STD: Sexually Transmitted Diseases; MEM: Minimum Essential Medium; SFB: Fetal Bovine Serum; RNA: Ribonucleic Acid; F: Primer-Sense; R: Primer-Antisense; RT-PCR: Reverse Transcription and Polymerase Chain Reaction

\section{ABSTRACT}

Introduction: E6 and E7 are viral oncoproteins of Human Papilloma Viruses (HPV) that can modulate several innate pathways related to the immune system blocking the production of cytokines such as IL-1 $\beta$. Until now, it is unknown if the ability of the Rhopalurus junceus scorpion venom to decrease the viability of tumor cells is related to the modulation of the expression levels of HPV16 viral oncogenes E6 and E7 (16E6E7).

Objective: To evaluate in vitro the antitumoral and modulatory properties of the Rhopalurus junceus scorpion venom in cervix cancer cells positive for HPV16. Materials and Methods: Cell viability was analyzed by MTT assay and morphological changes were observed by phase contrast microscopy in SiHa cell line treated with $R$. junceus scorpion venom for $72 \mathrm{~h}$. The expression of 16E6E7 and p53 genes were examined trough real time RT-PCR and end-point RT-PCR, respectively, after 24 and $48 \mathrm{~h}$ of treatment of SiHa cells with $R$. junceus scorpion venom. Finally, the supernatant was harvested and quantified for IL-1 $\beta$ by ELISA after 24 and $48 \mathrm{~h}$ of incubation.

Results: $R$. junceus scorpion venom decreased the viability of SiHa cells and induced morphological changes. Analysis of expression of 16E6E7 and p53 by RT-qPCR and RTPCR, respectively, showed a reduction of E6 and E7and increase in p53 genes expression after $24 \mathrm{~h}$ of the incubation in the treated cells respect to the untreated control. While the production of IL- $1 \beta$ by the SiHa cells treated with $0.5 \mathrm{mg} / \mathrm{mL}$ and $1 \mathrm{mg} / \mathrm{mL}$ of $R$. junceus scorpion venom, increased significantly at $48 \mathrm{~h}(\mathrm{p}<0.05)$.

Conclusion: $R$. junceus scorpion venom has antiviral potential by modulating the in vitro expression of the E6 and E7 oncogenes that lead to a cytotoxic effect on the cervical cancer positive for HPV16.

\section{Introduction}

Human Papilloma Virus (HPV) comprises a diverse group of DNA viruses belonging to the Papillomaviridae family and represents one of the sexually transmitted diseases (STD) with the highest incidence [1]. Viral oncoproteins E6 and E7 can deregulate several innate pathways related to the immune system that block the production of cytokines such as IL-1 $\beta$ [2,3]. In spite that prophylactic vaccines have been developed to prevent HPV infection, these are not effective on active HPV infections, showing no therapeutic 
effect [4]. In women, cervical-uterine cancer is the second most frequent in underdeveloped countries, while worldwide it is the fourth in incidence and mortality [5]. This fact is highly linked to persistent infections with HPV genotype 16 (HPV16) [6]. Tumor cells often show high expression of E6 and E7 and in many cases with integration of viral DNA into the host cell genome [7]. The E6 viral oncoprotein of HPV16 promotes the degradation of the tumor suppressor gene p53, which prevents the induction of cell cycle arrest and apoptosis of cervical-uterine tumor cells [8]. The conventional antineoplastic treatments used are not applicable in all cases and produce undesirable side effects [9]. Natural products have been identified as promising sources of drugs for cancer treatment and prevention [10]. For example, curcumin, witaferin A, and epigallocatecin-3-gallate are cytotoxic for cervical cancer cells positive for HPV and negatively modulate the expression of one or both viral oncoproteins (E6 and E7), resulting in the loss of the transforming phenotype and the inhibition of cell growth $[11,12]$.

The Rhopalurus junceus scorpion ( $R$. junceus) is an endemic species from Cuba that belongs to the Buthidae family. In vitro studies have shown that it exerts a selective cytotoxic effect on cancer cell lines of epithelial origin without affecting normal cells [13]. The antineoplastic effect of this scorpion venom includes the induction of apoptosis, which was observed in the cervical cell line HeLa positive for HPV18 [13] and in the metastatic breast cancer cell line MDA-MB-231 [14]. However, it is unknown whether the ability of the venom $R$. junceus to decrease the viability of cervicaluterine tumor cells is related to the modulation of the expression levels of HPV16 viral oncogenes E6 and E7 and IL-1 $\beta$.

\section{Methods}

\section{Venom Source}

Female and male adults Rhopalurus junceus scorpions, collected in Isla de la Juventud special municipality from Cuba were kept in captivity for at least 1 month before venom extraction by electrical stimulation. Scorpions were maintained under bioterium conditions in individual plastic containers at $23 \pm 1^{\circ} \mathrm{C}$ temperature, $60 \pm 10 \%$ relative humidity and $12: 12 \mathrm{hr}$ light-dark cycle in laboratories belonging to Laboratories of Biopharmaceuticals and Chemicals Productions (LABIOFAM). The obtaining, bioterium condition, management of scorpion colonies, and collection of venom have been approved by the Ministry of Science, Technology and Environment of Cuba (CITMA 20/2016). Venom was dissolved in distilled water and centrifuged at $1650 \mathrm{~g}$ for $15 \mathrm{~min}$. The supernatant was filtered by using a $0.2 \mu \mathrm{m}$ syringe filter and stored at $-20{ }^{\circ} \mathrm{C}$ until used. The protein concentration was calculated by the Lowry modified method [15].

\section{Cell Line and Culture}

SiHa (cervix squamous cell carcinoma grade II ATCC HTB-35 $5^{\mathrm{TM}}$ ) cell line was maintained in minimum essential medium (MEM), supplemented with $2 \mathrm{mM}$ of glutamine and non-essential amino acids, $10 \%$ of fetal bovine serum (SFB) and penicillin-streptomycin $100 \mathrm{UI} / \mathrm{mL}-100 \mu \mathrm{g} / \mathrm{mL}$. The cells were grown in a humidified atmosphere, $5 \% \mathrm{CO}_{2}$ at $37 \stackrel{\circ}{\circ}$.

\section{Isolation and Quantification of Total RNA}

The SiHa cell line $\left(1 \times 10^{5}\right.$ cells $\left./ \mathrm{mL}\right)$ was grown in flat-bottom 24-well cell culture plates and incubated for $24 \mathrm{~h}$ and $48 \mathrm{~h}$ with $0.25 \mathrm{mg} / \mathrm{mL}, 0.5 \mathrm{mg} / \mathrm{mL}$ and $1 \mathrm{mg} / \mathrm{mL}$ of $R$. junceus scorpion venom diluted in culture medium. At the end of each incubation period, the culture supernatant from each well was collected (three replicates of each treatment were mixed) and $140 \mu \mathrm{L}$ were taken from each sample and to perform automatic RNA extraction using the commercial Qiamp viral RNA kit (Qiagen) using the Qiacube equipment (Qiagen) following the manufacturer's instructions. The concentration of total ribonucleic acid (RNA) in the samples was determined using a Biophotometer (Eppendorf, Germany).

\section{RT-qPCR Analysis of E6 and E7 Genes from VPH-16}

The commercial QuantiFast Multiplex RT-PCR kit (QIAGEN, USA) was used for the analysis. The reaction mix (for 10 reactions) contained $12.5 \mu \mathrm{L}$ of $2 \mathrm{X}$ QuantiFast Multiplex RT-PCR Master Mix (HotStarTaq Plus DNA polymerase, QuantiFast Multiplex RTPCR buffer, and dNTP mix (dATP, dCTP, dGTP, and dTTP)), $10 \mu \mathrm{L}$ of a 20X primer-probe solution $(0.4 \mu \mathrm{M}$ primer-sense $(\mathrm{F}), 0.4 \mu \mathrm{M}$ primer-antisense (R), $0.2 \mu \mathrm{M}$ probe), $2.5 \mu \mathrm{L}$ of QuantiFast RT Mix and $13 \mu \mathrm{L}$ of RNAse-free water. Each reaction included $15 \mu \mathrm{L}$ of this mixture and $5 \mu \mathrm{L}$ of RNA. After that, it's were each reaction tube was centrifuged at $55 \mathrm{~g}$ for a few seconds in a refrigerated centrifuge (Eppendorf, Germany) and placed in the thermal cycler (LightCycler 1.5 Roche, USA). Amplification was carried out in 45 cycles, with an initial cycle of reverse-transcription of $20 \mathrm{~min}$ at 50 ${ }^{\circ} \mathrm{C}$ followed by a PCR activation step of $5 \mathrm{~min}$ at $95^{\circ} \mathrm{C}$ and then 45 cycles with the denaturation steps of $15 \mathrm{~s}$ at $95^{\circ} \mathrm{C}$, hybridization and extension of $30 \mathrm{~s}$ at $60{ }^{\circ} \mathrm{C}$. The sequences of the primers used were for HPV16 F: 5'-GAA CCG AAA CCG GTT AGT ATA A-3 'and for HPV16 R: 5'-ATG TAT AGT TGT TTG CAG CTC TGT-3'. The sequence of the 128 bp probe was 5'-Fam-CAT TTT ATG CAC CAA AAG AGA ACT GCA ATG TTT C-BHQ1-3 'at 40nM. The sequence of the $\beta$ globin (bG) gene, which was used as a constitutive expression control, was bG F: 5'-ACA CAA CTG TGT TCA CTA GC-3' and for bG R: 5'-CAA CTT CAT CCA CGT TCA CC-3'. The sequence of the 5 'Y.Y.-TCA AAC AGA CAC CAT GGT GCA TCT GAC TCC -BHQ1 3' probe of 40nM and 110 bp. The delta delta $\mathrm{Ct}(\Delta \Delta \mathrm{Ct}$, Ct: cycle threshold) was calculated to determine the relative expression levels of HPV-16 E6 and E7. $\Delta \Delta$ $\mathrm{Ct}=\Delta \mathrm{Ct}$ (sample) $-\Delta \mathrm{Ct}$ (control: untreated) with $\Delta \mathrm{Ct}$ (sample) = Ct value of $\mathrm{E} 6$ and $\mathrm{E} 7$ for the sample (treatment with $R$. junceus scorpion venom) - Ct value with the $\beta$ globin gene for the sample and $\Delta \mathrm{Ct}$ (control) $=\mathrm{Ct}$ value of $\mathrm{E} 6$ and $\mathrm{E} 7$ for the control- $\mathrm{Ct}$ value with the $\beta$-globin gene for the control. Also, the number of times that the relative expression levels of HPV-16 E6 and E7 decreased 
for each of the evaluated concentrations of venom regarding to the control was calculated, using the following formula: $2^{-\Delta \Delta C t}$ (control) between $2-\Delta \Delta \operatorname{Ct}(R$. junceus).

\section{RT-PCR Analysis of p53 Gene Expression}

Reverse transcription and Polymerase Chain Reaction (RT-PCR) were performed in a single step using the commercial OneStep RTPCR kit (Quiagen Inc. Germany). A concentration of $100 \mathrm{ng}$ of total RNA was used for each treatment. PCR amplification was carried out in a Ther-mal cycler (AUXILAB, Spain). $\beta$-actin gene amplification was performed as an internal control gene. The primer sequence for RT-PCR was 5'-CCTTCCTGGGCATGGAGTCCTG-3' and 5'-GGAGCAATGATCTTGATCTTC- $3^{\prime}$ for $\beta$-actin, $5^{\prime}$-GGGTTAGTTTACAATCAGCCACATT- $3^{\prime}$ and $5^{\prime}$-GGCCTTGAAGTTAGAGAAAATTCA-3' for $\mathrm{p} 53$. The initial step of reverse transcription was carried out at $30 \mathrm{~min}$ at $50{ }^{\circ} \mathrm{C}$, while the initiation step of the PCR at $95^{\circ} \mathrm{C}$ for 15 min. PCR conditions were 40 cycles at $94^{\circ} \mathrm{C}$ for $60 \mathrm{sec}$, at $60^{\circ} \mathrm{C}$ for $60 \mathrm{sec}$ at $72{ }^{\circ} \mathrm{C}$ for $1 \mathrm{~min}$. Amplified PCR products were subjected to electrophoresis at $70 \mathrm{~V}$ in $1.5 \%(\mathrm{w} / \mathrm{v})$ agarose gel for $90 \mathrm{~min}$. The gels were examined and the intensity of each band was measured by using ImageJ 1.46 software.

\section{In Vitro Cell Viability Assay (MTT Assay)}

The effect of scorpion venom on cell viability was determined by the MTT assay (Mosmann, 1983). SiHa cells (1x104/well) were plated in $50 \mu \mathrm{l}$ of medium/well in 96-well culture plates (Costar Corning, Rochester, NY) and incubated overnight in a humidified atmosphere of $5 \%(\mathrm{v} / \mathrm{v}) \mathrm{CO}_{2}$ at $37^{\circ} \mathrm{C}$ to recovery and cell adhesion in a humidified atmosphere of $5 \%(\mathrm{v} / \mathrm{v}) \mathrm{CO}_{2}$ at $37^{\circ} \mathrm{C}$. After incubation, $50 \mu \mathrm{l}$ of different scorpion venom amounts dissolved in medium were added at final concentration of venom at $0.0625,0.125$ $0.25,0.5$ and $1 \mathrm{mg} / \mathrm{mL}$ in each well. Cells with culture medium and without scorpion venom were used as untreated control. Five wells were included in each concentration. After treat-ment for $72 \mathrm{~h}$, $10 \mu \mathrm{l}$ of $5 \mathrm{mg} / \mathrm{mL}$ of sterile MTT was added per well and cultivated for another $3 \mathrm{~h}$. The supernatant was carefully removed, $150 \mu \mathrm{l}$ DMSO was added per well and incubated for $15 \mathrm{~min}$ at $37^{\circ} \mathrm{C}$. The absorbance was measured with a microplate reader (ELISA MRX Revelation Dynex Technologies 560nm with 630nm as reference). Absorbance from untreated cells was considered as 100\% of growth and used for viability calculation. The effect of scorpion venom on the viability for human cell lines panel was expressed as the \% viability, using the formula: \%viability $=A_{560-630 \mathrm{~nm}}$ of treated cells / A560-630nm of control cells x 100\%. The IC50 values (venom concentration that causes $50 \%$ reduction of cell) from cancer cells were determined. The experiments were performed three times.

\section{Phase Contrast Microscopy}

The cells were washed with PBS after $72 \mathrm{~h}$ of treatment. Morphological changes in culture were then observed under microscope IX-71 (Olympus Corporation, Tokyo, Japan). Images were captured using the camera DP-72 (Olympus Corporation, Tokyo, Japan) and 10X objectives.

\section{Determination of IL-1 $\beta$ Levels in the Culture Supernatant}

The supernatants of the SiHa cells treated for 24 and 48 hours with $0.25,0.5$ and $1 \mathrm{mg} / \mathrm{mL}$ of $R$. junceus scorpion venom were collected and the presence of the cytokine IL-1 $\beta$ (Catalog number: 559603) was determined using a commercial ELISA kit (BD OptEIA ?]; BD Biosciences, San Diego, CA, USA) according to manufacturer's recommendations. Two independent experiments were performed with three replicates each.

\section{Statistical Analysis}

Results are presented as the mean \pm standard error media (SEM). The $\mathrm{IC}_{50}$ values were determined by interpolation of tendency line from linear regression curve. Statistical analysis was performed by Kruskall Wallis, post-test: Dunn, using GraphPad Prism version 5.01 for Windows, (GraphPad Software, San Diego California, USA). Significant differences were considered for $\mathrm{p}<0.05$.

\section{Results}

Treatment of SiHa cells with $R$. junceus scorpion venom during $72 \mathrm{~h}$ induced significant differences with respect to the control for concentrations of $0.5 \mathrm{mg} / \mathrm{mL}(\mathrm{p}<0.05)$ and $1 \mathrm{mg} / \mathrm{mL}(\mathrm{p}<0.001)$ (Figure 1A). The IC50 value found by linear regression analysis from the percentage of viable cells for the treatment with $0.0625-1 \mathrm{mg} /$ $\mathrm{mL}$ of $R$. junceus scorpion venom was $1.1 \mathrm{mg} / \mathrm{mL}$. While a loss of cell morphology and the rupture of the monolayer were the changes observed in the SiHa cells treated with this scorpion venom and the total rupture of the monolayer was observed for the highest concentration evaluated (Figure 1B). The relative expression values of E6 and E7 (16E6E7) HPV16 viral oncogenes achieved by RT-qPCR are shown in the Figure 2 A decrease in the expression of the viral genes E6 and E7 of HPV16 was observed in all evaluated concentrations being more pronounce at $24 \mathrm{~h}$ of incubation. In $\mathrm{SiHa}$ cells treated with $0.25,0.5$ and $1 \mathrm{mg} / \mathrm{mL}$ of $R$. junceus scorpion venom for $24 \mathrm{~h}$, the expression of 16E6E7 decreased in 4.2, 6.8 and 3.5 times regarding to untreated cells. While after $48 \mathrm{~h}$ of incubation with $0.25,0.5$ and $1 \mathrm{mg} / \mathrm{mL}$ of $R$. junceus scorpion venom, the level expression of 16E6E7 decreased in 1.3, 1.4 and 1.1 times with respect to the untreated control. There was an increase of the p53 gene expression regarding to the untreated cells in all evaluated 
concentrations of $R$. junceus scorpion venom (Figure 3). SiHa cells treated with $0.25,0.5$ and $1 \mathrm{mg} / \mathrm{mL}$ of $R$. junceus scorpion venom at $24 \mathrm{~h}$, increased the expression levels of p53 in 8.1, 14.6 and 6.3 times, respectively, with respect to the untreated cells (Figure $3 \mathrm{~A}$ ). After $48 \mathrm{~h}$ of incubation with the same concentration of this venom, the expression levels of p53 was increased in 10.5, 16.4 and 6.9 times, respectively, with respect to the untreated control (Figure 3B). There was a tendency to increase IL- $1 \beta$ production by the $\mathrm{SiHa}$ cells treated with $R$. junceus scorpion venom was shown (Figure 4). Statistically significant differences were only observed between the untreated cells and the treated with 0.5 and $1 \mathrm{mg} / \mathrm{mL}$ of $R$. junceus scorpion venom after $48 \mathrm{~h}$ of incubation $(\mathrm{p}<0.05)$.

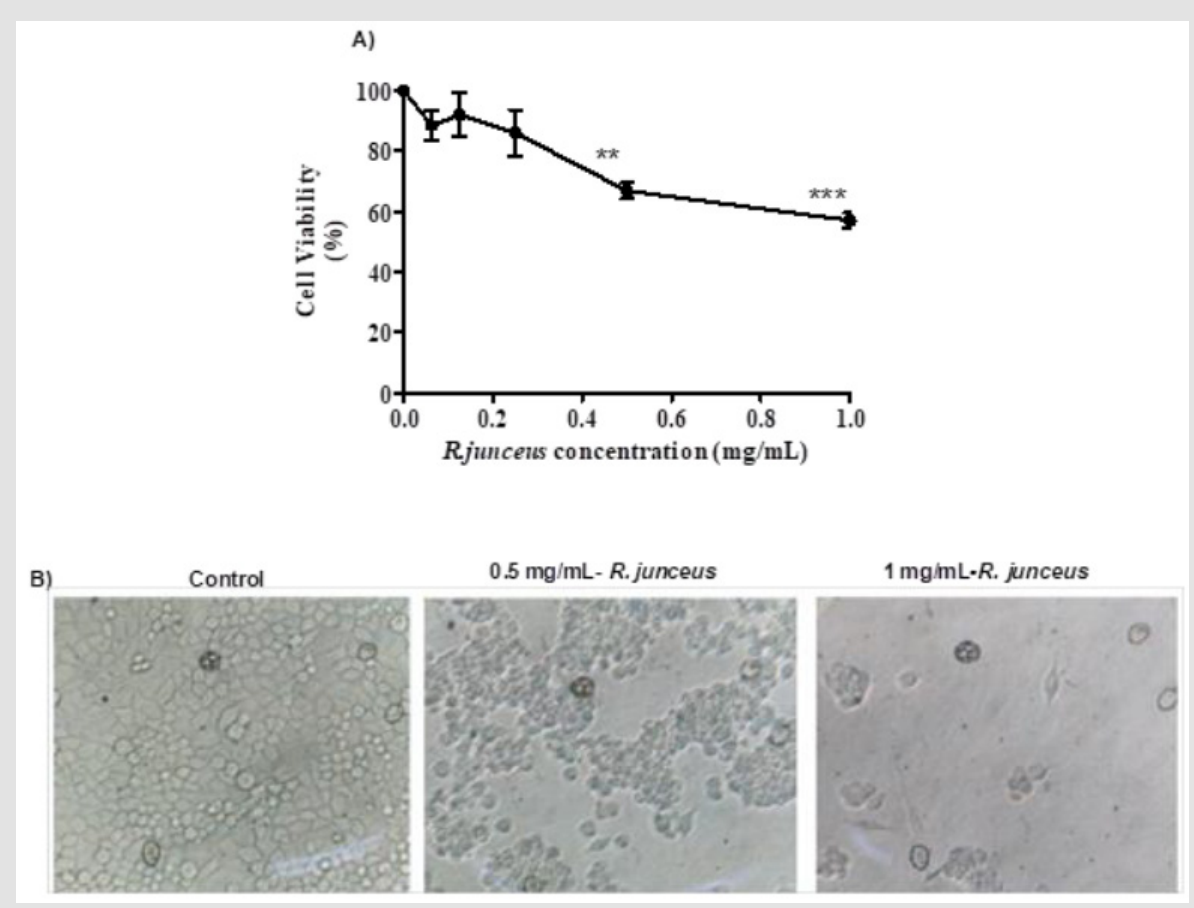

Figure 1: Effect of Rhopalurus junceus scorpion venom on the SiHa cells.

A. Viability of SiHa cells treated with $0.0625-1 \mathrm{mg} / \mathrm{mL}$ of $R$. junceus scorpion venom for $72 \mathrm{~h}$.

B. Morphology of SiHa cells untreated and treated with $0.5 \mathrm{mg} / \mathrm{mL}$ and $1 \mathrm{mg} / \mathrm{mL}$ of $R$. junceus scorpion venom. Values represent the mean \pm SEM achieved from three independent experiments. Significant differences ${ }^{* *} p<0.01,{ }^{* * *} p<0.001$.

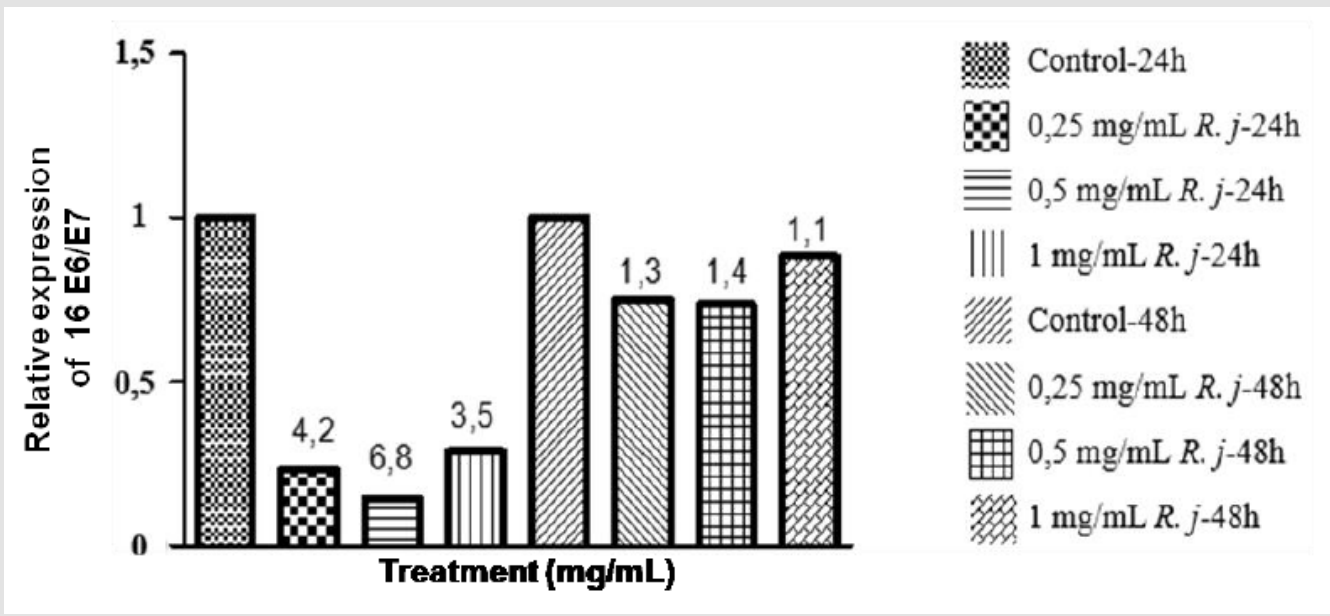

Figure 2: Effect of $R$. junceus scorpion venom on the expression of E6 and E7 oncogenes in SiHa cancer cell line.

Note: Relative expression values of E6 and E7 HPV16 viral oncogenes normalized with the $\beta$-globin gene in treated cells with $0.25,0.5$ and $1 \mathrm{mg} / \mathrm{mL}$ of $R$. junceus (R. j) scorpion venom and untreated cells during 24 and 48 hours. The values over the bar represent the reduction times of the relative expression of $16 \mathrm{E} 6 \mathrm{E} 7$ of cells treated with $R$. junceus scorpion venom regarding to the control. 

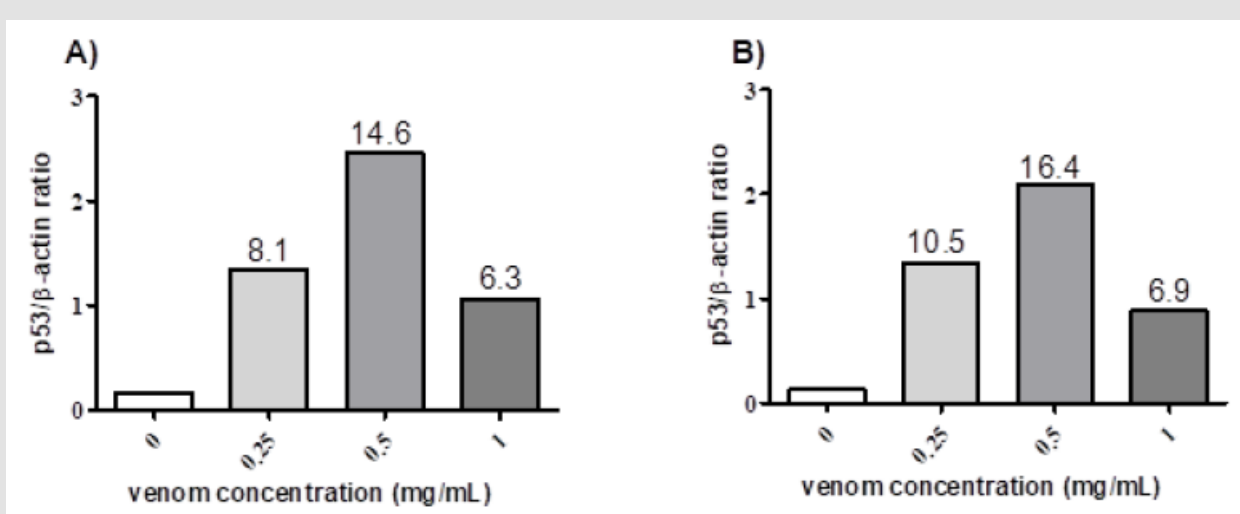

Figure 3: Effect of $R$. junceus scorpion venom in the expression of the p53 gene in SiHa tumor cell line.

Note: Relative signal intensities of p53 mRNAs expression levels were compared with $\beta$-actin at $24 \mathrm{~h}$ (A) and $48 \mathrm{~h}$ (B). The $\beta$-actin gene was used as a constitutive expression control. The values over the bar represent the times of reduction the relative expression of $\mathrm{p} 53$ of cells treated with $R$. junceus scorpion venom respect to the control. The intensity of the bands was measured using the free software ImageJ version 1.46.
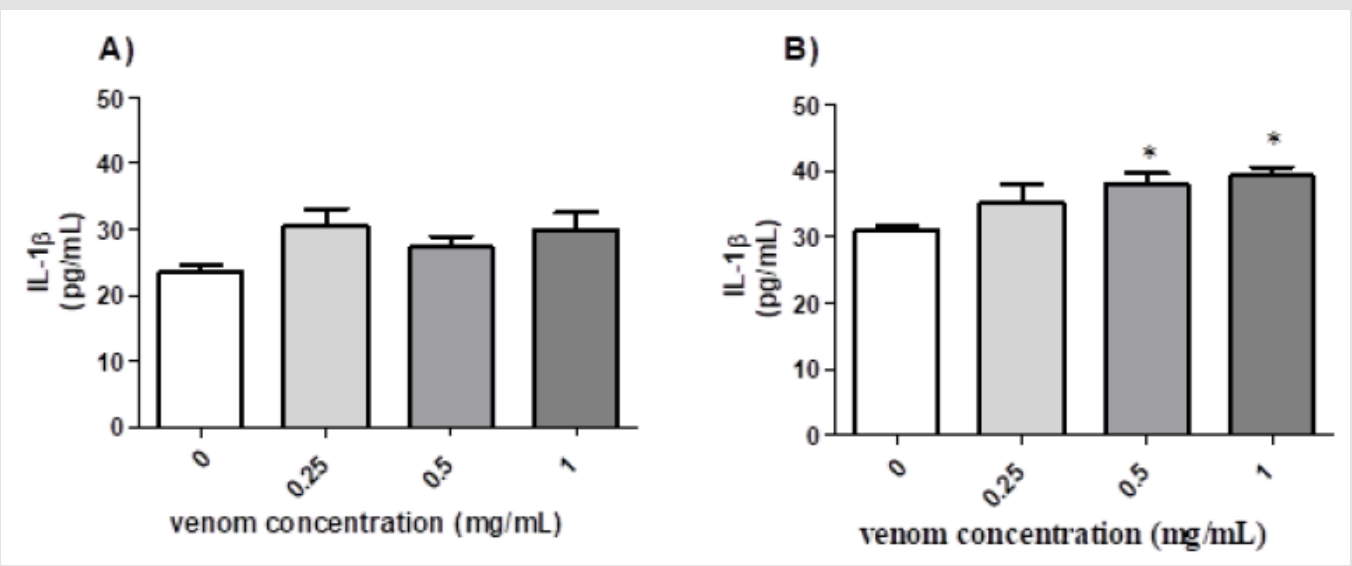

Figure 4: Levels of IL-1 $\beta$ in supernatant of SiHa treated with $R$. junceus scorpion venom.

Note: The mean \pm standard deviation of the IL- $1 \beta$ concentration present in supernatant of SiHa treated with $0.25,0.5$ and 1 $\mathrm{mg} / \mathrm{mL}$ of $R$. junceus scorpion venom for $24 \mathrm{~h}(\mathrm{~A})$ and $48 \mathrm{~h}(\mathrm{~B})$. Control represents cells treated with culture medium. Significant differences ${ }^{*} \mathrm{p}<0.05$.

\section{Discussion}

In women, cervical-uterine cancer is the second most frequent in underdeveloped countries, while worldwide it is the fourth in incidence and mortality [5]. This incidence is highly linked to persistent infections with HPV16 [6]. Preclinical studies have demonstrated the antitumoral effect of scorpion venoms [16] and their antiviral potentialities [17]. R. junceus scorpion venom decreases the viability of epithelial tumor cells such as cervical cancer cell line positive for HPV16 [13]. However, it is unknown whether the antitumoral effect of $R$. junceus scorpion venom is related to the modulation of the expression of viral oncogenes E6 and E7 and the antiviral cytokine IL-1 $\beta$. The loss viability of SiHa cell line induced by $R$. junceus scorpion venom and the IC50 value agree with previous studies where this venom was evaluated in human tumor cell line panel [13]. Also, natural products how the crude venom of Tityus serrulatus scorpion venom demonstrated a concentration dependent cytotoxic effect in SiHa and HeLa cervix cancer cells [18]. However, there are scorpion venoms that do not exert antiproliferative effect on the cervical cancer tumor lines. For example, the crude venom of the Centruroides limpidus limpidus (C. limpidus) scorpion does not affect the growth of HeLa cells (Contreras-Ortiz et al., 2013) [19], which showed 100\% cell viability after exposure to a dose range $C$. limpidus scorpion venom $(0.5-4 \mathrm{mg} / \mathrm{mL})$ higher than the evaluated range in this study.

The reduction of the viability in SiHa cells induced from $R$. junceus scorpion venom is associated with the appearance of morphological changes in this cell line. The results show that the highest concentration of this venom causes the loss of cell 
morphology and a total rupture of the monolayer with respect to untreated cells. These morphological changes agree with previous results reported for this scorpion venom in tumor cells HeLa [13] and MDAMB231 [14]. Furthermore, a similar morphological change is induced by Tityus serrulatus scorpion venom in SiHa and HeLa cells [18]. Currently, this is the first study that demonstrates the influence of $R$. junceus scorpion venom in the reduction of E6 and E7 viral genes of HPV16 on the SiHa cells. Previously, it was showed that E6 and E7 oncoproteins are expressed jointly in the course of HPV infection with oncologic high risk (HPV-HR) and in the subsequent development of cancer [20]. Our results agree with another research based in natural products, such as the curcumin which is able to inhibit the expression of E6 and E7 viral oncogenes evidenced by RT-PCR and Western Blotting (Divya et al., 2006) . Also, the witaferin A decreases the expression of E6 oncoprotein in cervical-uterine tumor cells CaSki positive for HPV16 and HPV18 [21]. Similarly, it has been corroborated that aloe-emodin decreases the expression of E6 and E7 proteins related in tumor cells positive for HPV18 (HeLa) and HPV16 (SiHa), respectively (Gao et al., 2019). However, it is necessary to deep in studies about action mechanism of $R$. junceus scorpion venom in human cervical-uterine cancer cells positive and negative for HPV. The E6 viral oncoprotein of HPV16 promotes the degradation of the tumor suppressor gene $\mathrm{p} 53$, which prevents the induction of cell cycle arrest and apoptosis of cervicaluterine tumor cells [8]. $R$. junceus scorpion venom increased the expression levels of the pro-apoptotic gene p53 in SiHa cells. Previously, our group of work had been reported that this venom induces apoptosis in [13] and in MDA-MB-231 [14] tumor cells. Treatment with this scorpion venom causes an overexpression of the pro-apoptotic genes p53, bax, noxa, puma, caspase 3 and p21; as well as in a decrease in the expression of the anti-apoptotic genes bcl-2 and bcl-xL in HeLa [13] and MDAMB231 [14]. While aloeemodin promotes apoptosis dependent of p53 in HeLa and SiHa cells [22]. A better understanding of p53-mediated apoptosis is essential, based in the use of scorpion venom, as it is promising for potential clinical applications. Also, it is necessary to elucidate the possible promotion of other p53 independent apoptotic cell death mechanisms induced by $R$. junceus scorpion venom in cervicaluterine cancer cell lines positive for HPV16.

An interesting result in this study was the increase of IL-1 $\beta$ in SiHa cells treated with $R$. junceus scorpion venom, which was statistically significant at concentrations of 0.5 and $1 \mathrm{mg} / \mathrm{mL}$ of this venom after $48 \mathrm{~h}$ of incubation. Previous study showed that 16E6E7 block IL-1 $\beta$ production in HPV16 infected keratinocytes and in cervical cancer derived cells lines [8]. The E6 oncoprotein forms a complex with ubiquitin ligase E6-AP and the tumor suppressor p53, leading to degradation of pro-IL-1 $\beta$ and impaired the IL-1 $\beta$ production [3]. Therefore, the inhibition of IRF6 by E6 is a strategy escape used by HPV16 to block the production of IL-1 $\beta$. The fight between oncoviral persistence and host immunity is focused in the regulation of IL-1 $\beta$ [8]. For that reason, the increase of IL-1 $\beta$ suggests its antiviral potentialities against HPV16 as a consequence of the exposure of SiHa cells to the R. junceus scorpion venom [22].

\section{Conclusion}

Rhopalurus junceus scorpion venom induces loss viability and induces morphological changes on SiHa cervical cancer cell line positive for HPV16. Also, treatment of SiHa with Rhopalurus junceus scorpion venom decreases the expression of E6 and E7 oncogenes of HPV16, increases the expression of the pro-apoptotic gene p53 and the levels of the cytokine IL-1 $\beta$ in the culture supernatant. For that reason, it can be explored as a possible therapeutic agent for the prevention and treatment of cervical cancers and other types of cancer related to HPV16.

\section{Conflict of Interest}

The authors declare no conflict of interest.

\section{Acknowledgment}

The authors are grateful to colleagues from Virology Department Technical, especially to Celeste Ramírez Cardentey, Odalys Valdés Ramírez, Rosmery Roque Arrieta and Guelsys González Báez, as well as scientific Support Department of Tropical Medicine Institute "Pedro Kourí" in their support to maintain cell culture. Besides, authors want to acknowledge particularly the assistance of the personnel from the scorpion Bioterium especially to personal of scorpion bioterium facilities LABIOFAM-Isla de la Juventud.

\section{Funding}

Authors confirm that this research did not receive any specific grant from funding agencies in the public, commercial, or not-forprofit sectors.

\section{References}

1. Gómez BP, Y Aragonés N (2016) Epidemiología del Virus del Papiloma Humano y el cáncer de cabeza y cuello. Revisiones en cáncer 30(4): 1-2.

2. Karim R, Meyers C, Backendorf C, Kristina Ludigs, Rienk Offringa, et al. (2011) Human papillomavirus deregulates the response of a cellular network comprising of chemotactic and proinflammatory genes. Plos One 6 (3): 1-12.

3. Niebler M, Qian X, Höfler D, Vlada Kogosov, Jittranan Kaewprag, et al. (2013) Post-translational control of IL-1 $\beta$ via the human papillomavirus type 16 E6 oncoprotein: a novel mechanism of innate immune escape mediated by the E3-ubiquitin ligase E6-AP and p53. Plos Pathog 9 (8): $1-16$.

4. Pimienta Rodríguez ET, Marrero Domínguez K, Y Fando Calzada R (2017) Candidatos vacunales profilácticos de segunda y tercera generación contra el Virus del Papiloma Humano. Revista CENIC Ciencias Biológicas 48(2): 21-32.

5. Arbyn M, Weiderpass E, Bruni L, De Sanjosé S, Saraiya M, et al. (2020) Estimaciones de incidencia y mortalidad de cáncer cervical en 2018: un análisis mundial. The Lancet Global Health 8(2): E191-E203. 
6. Bray F, Ferlay J, Soerjomataram I, Siegel RL, Torre LA y Jemal A (2018) Estadísticas mundiales sobre el cáncer 2018: estimaciones globales de incidencia y mortalidad en todo el mundo para 36 cánceres en 185 países. CA: una revista de cáncer para médicos 68(6): 394-424.

7. Huang LW, Chao SL, Y Lee BH (2008) La integración del Virus del Papiloma Humano tipo 16 y tipo 18 es un evento muy temprano en la carcinogénesis cervical. Revista de patología clínica 61(5): 627-631.

8. Ainouze M, Rochefort P, Parroche P, Roblot G, Tout I, et al. (2018) Human papillomavirus type 16 antagonizes IRF6 regulation of IL-1 $\beta$. PLoS Pathog 14(8): 1-27.

9. Topcul M, Cetin I (2014) Endpoint of cancer treatment: targeted therapies. Asian Pac J Cancer Prev 15(11): 4395-4403.

10. Liu CC, Yang H, Zhang LL, Zhang Q Chen B, et al. (2014) Biotoxins for cancer therapy. Asian Pac J Cancer Prev 15(12): 4753-4761.

11. Kumar S, Jena L, Galande S, Daf S, Mohod K, et al. (2014) Elucidating molecular interactions of natural inhibitors with VPH-16 E6 oncoprotein through docking analysis. Genomics y informatics 12(2): 64-70.

12. Zhu Y, Huang Y, Liu M, Yan Q, Zhao W, et al. (2019) Epigallocatechin gallate inhibits cell growth and regulates miRNA expression in cervical carcinoma cell lines infected with different highrisk human papillomavirus subtypes. Experimental and therapeutic medicine 17(3): $1742-1748$

13. Díaz García A, Morier Díaz L, Frión Herrera Y, Rodríguez Sánchez $H$, Caballero Lorenzo Y, et al. (2013) In vitro anticancer effect of venom from Cuban scorpion Rhopalurus junceus against a panel of human cancer cell lines. Journal of venom research 4: 5-12.

14. Díaz García A, Ruiz Fuentes JL, Rodríguez Sánchez H, Y Castro JAF (2017) Rhopalurus junceus scorpion venom induces apoptosis in the triple negative human breast cancer cell line MDA-MB-231. Journal of venom research 8: 9-13

\section{ISSN: 2574-1241}

DOI: 10.26717/BJSTR.2021.36.005816

Arianna Yglesias Rivera. Biomed J Sci \& Tech Res

(C) This work is licensed under Creative Commons Attribution 4.0 License

Submission Link: https://biomedres.us/submit-manuscript.php
15. Herrera Y, Heras N, Y Cardoso D (1999) Adaptación a microplacas y validación de la técnica de Lowry. VacciMonitor 3: 7-11.

16. Moradi M, Solgi R, Vazirianzadeh B, Tanzadehpanah H, Y Saidijam M (2018) Scorpion venom and its components as new pharmaceutical approach to cancer treatment, a systematic review. Int J Pharm Sci Res 9(7): 2604-2615.

17. Da Mata ÉCG, Mourão CBF, Rangel M, Y Schwartz EF (2017) Antiviral activity of animal venom peptides and related compounds. Journal of Venomous Animals and Toxins including Tropical Diseases 23(1): 3-10.

18. Bernardes-Oliveira E, Gomes DL, Martelli Palomino G, Juvenal Silva Farias K, Da Silva, et al. (2016) Bothrops jararaca and bothrops erythromelas snake venoms promote cell cycle arrest and induce apoptosis via the mitochondrial depolarization of cervical cancer cells. Evidence-Based Complementary and Alternative Medicine 2019: 1-8.

19. Contreras-Ortiz JME, Vazquez Chagoyan JC, Martinez Castaneda JS, Estrada Franco JG, Aparicio Burgos JE, et al. (2013) Resistance of cervical adenocarcinoma cells (HeLa) to venom from the scorpion Centruroides limpidus. Journal of Venomous Animals and Toxins Including Tropical Diseases 19 (20): 1-7.

20. Di Filippo Iriarte G, Y Orjuela JL (2019) Detección de ARNm de oncoproteínas E6 y E7 del Virus del Papiloma Humano en cáncer de cuello uterino. Acta bioquím. clín. latinoam 52 (3): 361-372.

21. Munagala R, Kausar H, Munjal C, Y Gupta RC (2011) Withaferin A induces p53-dependent apoptosis by repression of VPH oncogenes and upregulation of tumor suppressor proteins in human cervical cancer cells. Carcinogenesis 32(11): 1697-1705.

22. Gao R, Wu X, Huang Z, Wang B, Li F, et al. (2018) El efecto antitumoral del aloe-emodina en las células de cáncer cervical se asoció con el Virus de Papiloma Humano E6 / E7 y el metabolismo de la glucosa. OncoTargets y terapia 12: 3713-3721.

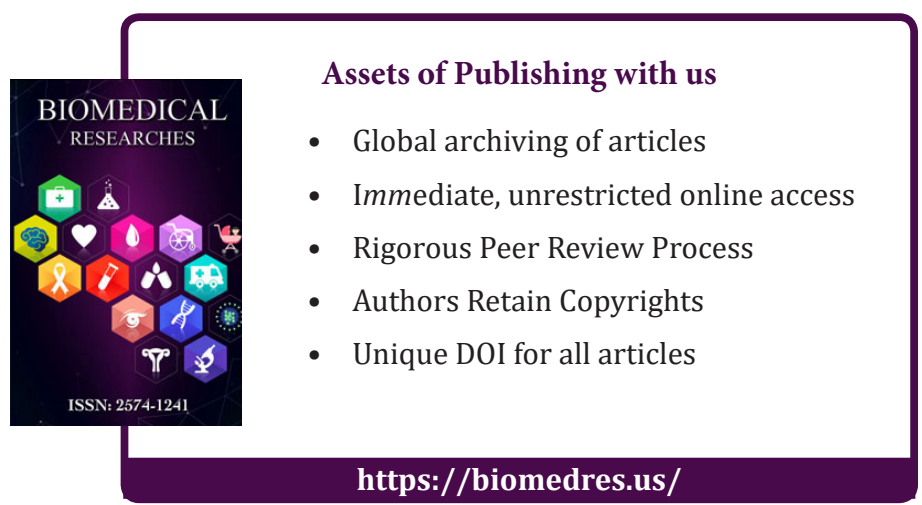

